\title{
POLITENESS STRATEGIES, LINGUISTIC MARKERS AND SOCIAL CONTEXTS IN DELIVERING REQUESTS IN JAVANESE
}

\author{
Sukarno \\ English Department, Faculty of Humanities, Universitas Jember, Indonesia \\ sukarno.sastra@unej.ac.id
}

First received: 4 August 2017

Final proof received: 31 January 2018

\begin{abstract}
Delivering request is not only influenced by linguistic factors, but also by socio-cultural factors. Some studies have reported the interaction between linguistic and socio-cultural factors in delivering requests in many different languages. However, this issue is rarely explored in Javanese (language). The aim of this study is to investigate the politeness strategies, the linguistic markers, and the social contexts commonly used to deliver requests in Javanese. The data were collected and sorted from the conversations among the Javanese people in Jember, East Java, Indonesia, when making speech acts to deliver requests. Having been sorted, the data were analysed using the deconstructive method to reveal the linguistic markers commonly used by the Javanese speakers to deliver requests and the social-cultural backgrounds which influence the choice of the politeness strategies. This research shows that (1) there are four types (most direct, direct, less direct, and indirect) of politeness strategies in Javanese, (2) there are four linguistic devices (sentence moods, speech levels, passive voice, and supposition/condition) as the markers of the politeness strategies and (3) the choices of the levels are strongly influenced by the social contexts (social distance, age, social status or power, and the size of imposition) among the tenors. The appropriate strategies for delivering requests in Javanese will make the communication among the interlocutors run harmoniously.
\end{abstract}

Keywords: politeness strategies; social-cultural backgrounds; requests; direct

According to Brown and Levinson (1987), politeness involves an awareness of other people's face wants. They believed that some speech acts such as orders, requests, and apologies were intrinsically face-threatening and were often referred to as face-threatening acts (FTAs). The study of the speech act of requests in different languages has received a great deal of attention by linguists. BlumKulka (1987) examined the notions of indirectness and politeness as applied to requests. Blum-Kulka, House, and Kasper (1989) compared requests across languages the realization patterns of requests and apologies to establish the similarities and differences between native and non-native speakers' realization patterns. Felix-Brasdefer (2005) investigated the notions of indirectness and politeness in the speech acts of requests among Mexican Spanish in the formal and informal situation. Anderson (2009) conducted research on polite requests in non-native varieties of English, the case of Ghanian English. Aubed (2012) made a research on the comparison of polite requests in English and Arabic for the purpose of translation. Finally, Salvesen (2015) compared politeness strategies in requests by Norwegian learners of English in comparison with native English speakers.

Several studies above indicate that delivering requests may vary among languages and cultures. What is polite and socially appropriate in one context or culture may be considered impolite or excessively polite in another (Anderson, 2009).
Some studies in communicative acts also proved that social norms might differ from one culture to another, so what is accepted in one culture could be rejected in another (Banikalef, Alladin, and Alnatour, 2015; Sukarno, 2010). Although speech act is controlled by universal pragmatic principles (Searle 1975, Brown and Levinson 1987, Leech 1983), they may vary in their verbalization across languages and cultures (Lee, 2003; Wierzbicka, 1992). Data from non-English speaking cultures indicate that many speech acts are perceived differently in the area of politeness in these cultures (Alsulami, 2015) because language and culture are inseparable (Wierzbicka, 1992). This article tries to identify the patterns of polite requests in Javanese since it is believed that the strategies the Javanese deliver requests are strongly bound by the Javanese cultures.

Studies on the Javanese politeness had also been conducted by some linguists, such as: how to use the Javanese lexicons for courtesy (Gonda, 1949, Sulistyowati, 2008), how to use the Javanese respect forms (Uhlenbeck, 1970), how to use the communicative codes in Javanese (Wolff \& Poedjosoedarmo, 1982), how to manage oral communications between superior and subordinators among the Javanese (Zaid, 1999), how to use the indirect speech acts in Javanese (Partana, 2006), how teach the Javanese respect usage to foreigners (Quinn, 2011), and how to respond to compliments politely in Javanese (Sukarno, 2015). Despite the 
fact that there are many researches on politeness in Javanese, researches on delivering requests in Javanese have received comparatively less attention, if not yet done. This study aims to answer the following research questions: (1) what types of politeness strategies can be identified in the language of Javanese spoken in Jember to deliver requests, (2) what linguistic devices can be identified to mark the polite requests, and (3) what socio-cultural backgrounds may motivate the speakers to use the politeness strategies in delivering requests.

Chiravate (2012) states that request is asking someone to do something which is beneficial to the speaker but costly to the hearer, and therefore request speech act involves the use of politeness strategies. Requests are particularly sensitive to the contexts of speaking and to the specific social characteristics of the requesters (Syahri, 2013). The speech act of requesting is chosen as the topic of this study for some reasons. Firstly, Javanese often make requests to their speech partners either directly or implicitly in their daily communication to give orders, instructions, do favours. Secondly, requesting speech acts are commonly performed by empowering the linguistic devices (sentence moods, passive voices, and conditional sentences) and make use of different levels of directness that show different personal and interpersonal relations. Furthermore, a request is a face-threatening act (Brown and Levinson, 1987). Finally, requesting speech acts are sensitive to certain parameters, such as social status, social distance, and degree of imposition. Such parameters influence the choice of formula and the level of directness in different languages (Abuarrah, Lochtman, \& Lutjerhams, 2013) including Javanese.

As for politeness strategies, some linguists (e.g., Lakoff, 1973, Brown \& Levinson, 1987;

$\begin{array}{lcll}(1) & (\mathrm{KI}): & \text { Menopo } & \text { panjengan } \\ (2) & (\mathrm{KM}): & \text { Nopo } & \text { sampeyan } \\ (3) & (\mathrm{Ng}): & \text { Opo } & \text { kowe } \\ & & \text { QW } & \text { you } \\ & & & \text { 'Did you buy new shirts?' }\end{array}$

In terms of speech levels, sentences (1) and (2) are classified as bhasa krama (KI, and KM) since they contain non-ngoko lexicon, such as mundhut and tumbas which are from the ngoko lexicon $t u k u$. Because the $\mathrm{Ng}$ level is the basic level, every concept which can be expressed in Javanese will be stated in a word or a phrase in the $\mathrm{Ng}$ style. In cases, where the KM and KI levels do not possess equivalent to the $\mathrm{Ng}$ words, the $\mathrm{Ng}$ words are used. Semantically, those sentences $(1,2,3)$ have the same referential meanings 'Did you buy new shirts', but pragmatically they have different meanings. In term of politeness, (1) is the least polite and (3) is the most polite. The right choice among the speech
Leech, 1983) believe that the goal of doing politeness is to save or to protect the face, which in turn it produces a good communication among the interlocutors. There are three rules of being polite from the perspective of the speaker. They are (1) don't impose, (2) give options, and (3) make the listener feel good, or be friendly (Lakoff, 1973). Furthermore, Leech (1983) formulates a "Politeness Principle" and its maxims. The function of this politeness principle and its maxims is to maintain the social relationship in friendly situations to enable the speaker to assure that cooperation will follow. In summary, the central point of politeness is how to manage 'face' in many different ways so that our partner of communication will not lose his 'face'. Therefore, interlocutors have to use specific strategies to minimize the threat according to a rational assessment of the face risk as an attempt to avoid FTAs (Maros \& Rosli, 2017).

However, politeness may differ crossculturally (Chen, 1993; Watts, Ide, \& Ehlich 1992; Holmes, 1988). In order to understand politeness in a certain language, it is important to examine some aspects of their culture particularly their fundamental values (Aziz, 2017). For example, to be polite in Javanese one must know some Javanese cultural concepts, namely: tata krama, andhap asor, and tanggap ing sasmito. Tata krama means tatanan bhasa 'the arrangements of language' or 'speech levels'. In relation to politeness, Poedjosoedarmo (1979), Errington (1982), and Herrick (1984) classify Javanese speech levels into three levels: the least polite, $N g o k o(\mathrm{Ng})$, the middle polite, Krama Madya (KM), and the most polite, Krama Inggil, (KI). Each level is a different one from another in their lexical items which can be demonstrated by the following examples.

$\begin{array}{lll}\text { mundhut } & \text { ageman } & \text { enggal? } \\ \text { tumbas } & \text { rasokan } & \text { anyar? } \\ \text { tuku } & \text { klambi } & \text { anyar? } \\ \text { buy } & \text { clothes } & \text { new }\end{array}$

levels of the sentences is determined by the social background among the tenors. For example, if the speaker speaks to a person whose social status is much higher than his (e.g., a student talks to his teacher), or his social distance is far (e.g., someone who speaks to a stranger) he will choose the KI style.

The next concept of the Javanese culture is andhap-asor. The phrase is lexically composed of two words: andhap 'low' and asor 'humble' which means lowering oneself while exalting others. This concept is rigidly implied in the Javanese syntactic structures as demonstrated by the following example. 
(4)

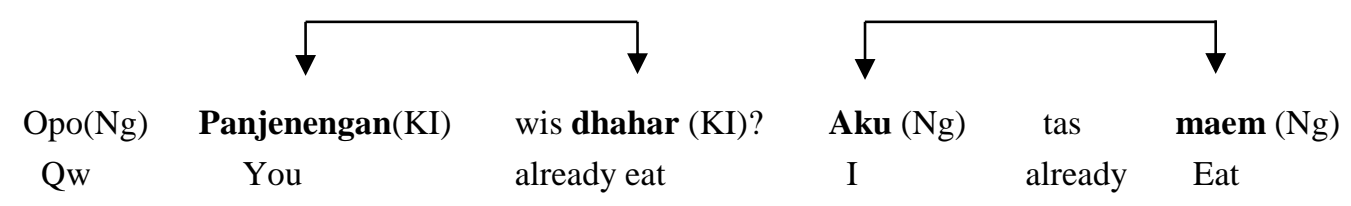

'Have you had breakfast/lunch/dinner?' 'I just had it.'

Both the words dhahar (KI) and maem $(\mathrm{Ng})$ in (4) have the same referential meaning, namely 'to have a meal', but they are different pragmatically. In the first clause, the verb refers to the other, or to the respected subject panjenengan 'the exalted you', so he must choose the KI lexicon dhahar to respect him. In contrast, when he refers to himself, $A k u$ 'I', he chooses the $\mathrm{Ng}$ verb form maem from the $\mathrm{Ng}$ style to denigrate himself. In other words, the reason of choosing the different verb forms for the same referential meaning in the politeness of Javanese is the realization of the Javanese cultural concept andhap asor (exalting others, while denigrating ourselves). Unlike English, this agreement rule also applies to the verb and its object as presented by the following examples.

(5) a

$\begin{array}{llll}\text { Ibu } & \text { ngongkon }(\mathrm{Ng}) & \text { adik }(\mathrm{Ng}) & \text { adus }(\mathrm{Ng}) \\ \text { Mother } & \text { ask } & \text { younger } & \text { a bath }\end{array}$

'Mother asked my younger to take a bath.'

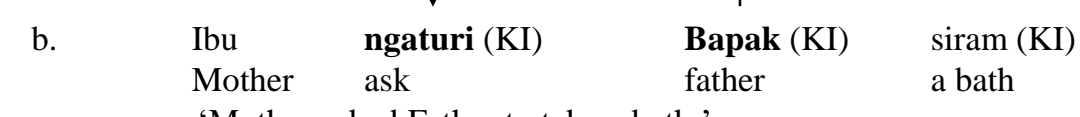

The motivation of using different verb forms in (5a) and (5b) is not governed by the subject, but by the object. In (5a), the object adik 'younger brother/sister' who has lower status than the Subject $\mathrm{Ibu}$ requires the $\mathrm{Ng}$ verb form ngongkon. In contrast, the object of (5b) Bapak who has a higher or similar social status than the subject $I b u$ needs the polite verb form from the KI lexicon ngaturi.

Finally, a good Javanese speaker should also

$$
\begin{aligned}
& \text { "Mas adoh mas, mengko kesuwen", } \\
& \text { brother far brother, take a long time }
\end{aligned}
$$

have a sense of tanggap ing sasmito which can be translated as the ability to interpret the hidden will of the speech partner. In Javanese, the speaker is not always necessary to express his or her feeling directly to the addressee because we have the culture of tanggap ing sasmito. The application of a sense of tanggap ing sasmito in Javanese can be illustrated by the following utterances, as quoted from Partana (2006).

$$
\begin{array}{cc}
\begin{array}{c}
\text { mengkono tembung-e } \\
\text { said-his }
\end{array} & \text { Safik } \\
& \text { Safik }
\end{array}
$$

'It is very far brother; it will take a long time, said Safik'
"Iki kontak-e, aja banter-banter",
wangsulane Azar
karo ngelungke
kontak montor-e
This key-the, not run fast-fast
reply Azar
with giving
key motor-his

'This is the key, don't ride too fast, replied Azar while giving the key of his motorcycle'

The quotation above indicates that the application of the concept of 'tanggap ing sasmito'. As a good Javanese, Azar can catch the hidden meaning delivered by Safik, by lending his motorcycle to him although he does not express his wish to borrow a motorcycle directly to Azar, for instance by saying aku nyilih montore 'I want to borrow your motorcycle'. Such an expression (making a request directly) can make a psychological imposition to the addressee because he can lose his face if he does not fulfil his speech partner's request.

\section{METHOD}

This study investigated the Javanese requesting strategies spoken in Jember, East Java, Indonesia, when they delivered requests. There are 20 participants taking part in this study. They were born and grew up in Jember, and other places where Javanese is most frequently used to communicate each other in their daily life. The data are naturally from the spoken language occurring between siblings, parents-children, uncle-cousin, employeeemployer, and between relatives. The situations 
occurred mostly in informal situations since Javanese is not used as an official language.

The data were collected by recording and note taking the conversations among the participants in many various situations, and purposes. The collected data were selected on the basis of sentences containing requests. Thus, particular attention is paid only to utterances where request speech acts happened. Based on the selection, it is found 25 utterances which are relevant to be analysed in this study. Having been selected, the data were transcribed and translated into English. The relevant utterances were analysed syntactically (to identify the linguistic markers, such as mood types, and voices) and pragmatically (to identify the social contexts, such as power, social distance, and imposition). The goal of this study is to identify and classify the requesting strategy types used by the
Javane speakers in Jember, Indonesia.

\section{RESULTS AND DISCUSSIONS}

In this study, the speech acts of delivering requests are analysed to identify the types of the politeness strategies, the linguistic markers empowering to build the types of the politeness strategies, and the social-cultural backgrounds which determine to choose of the appropriate requesting strategies. Adapting and modifying the directness scales of Blum-Kulka (1987), Blum-Kulka, et al. (1989) and Salmani-Nodoushan (2007), the result shows that there are four classifications of politeness strategies marked by the four linguistic units, and three elements of social context as presented in Table 1, and the discussion of each classification is presented respectively.

Table 1. Research result

\begin{tabular}{lll}
\hline Types of Requesting Strategies & Linguistic Markers & Social Context \\
\hline Most Direct Strategy & Imperative Mood & $\mathrm{P}: \mathrm{S}>\mathrm{H}$, \\
& Ng level & $\mathrm{A}: \mathrm{S}>\mathrm{H}$ \\
& & $\mathrm{SD}: \mathrm{Close} /$ Middle/Far \\
Direct $\quad$ Strategy & Declarative Mood & $\mathrm{P}: \mathrm{S}>\mathrm{H}$, \\
& Imperative Mood & $\mathrm{A}: \mathrm{S} \geq \mathrm{H}$ \\
& Ng level & $\mathrm{SD}:$ Middle / Far \\
& & \\
& Interrogative Mood & $\mathrm{P}: \mathrm{S} \leq \mathrm{H}$, \\
Less Direct Strategy & Supposition/Condition & $\mathrm{A}: \mathrm{S} \leq \mathrm{H}$ \\
& Passive Voice & $\mathrm{SD}:$ Middle / Far \\
& Ng or KM & \\
& & \\
& Interrogative Mood & $\mathrm{P}: \mathrm{S}<\mathrm{H}$, \\
Indirect Strategy & Supposition/Condition & $\mathrm{A}: \mathrm{S}<\mathrm{H}$ \\
& Passive Voice & SD: Middle / Far \\
& KI & Size of imposition \\
\hline
\end{tabular}

$\mathrm{P}=$ Power, $\mathrm{A}=\overline{\text { Age }, \mathrm{SD}=\text { Social Distance }}$

\section{Most direct strategy}

Linguistically, the most direct strategy of delivering the request in Javanese is realized by an imperative mood which is marked by an imperative suffix
(Imp), such as: '-en, or -no' and the Ngoko (Ng) speech level. In the following data, a father (as the requester) wants his son (the requestee) to do a favour (to clean a motorcycle) for the requester.

$\begin{aligned} & \text { Umbah-en } \\ & \text { Wash-Imp } \\ & \text { 'Wash this motorcycle.' }\end{aligned}$
$\begin{array}{lll}\text { Umbah-no motor } & \text { iki! (Ng) } \\ \text { this }\end{array}$
$\begin{aligned} & \text { Wash-Imp } \\ & \text { 'Wash this motorcycle/Have montor motorcycle washed.' }\end{aligned}$

In data (1) and (2), we find the imperative suffixes -en and -no respectively. The difference between them lies in the person who performs the action (the agent) and the person for whom the action is performed (the benefactor). From the agent perspective, the suffix -en shows that the agent is only the addressee, whilst, the suffix -no indicates that the agent of the action is not necessarily the addressee. Thus, in (1), it is the son (the requestee) who really washes the motorcycle, but in (2) the agent of the action can be the son or someone else whom the son asks to do so (to get this motorcycle washed).

Because data (1) suggests that the action must be done by the addressee, the use of the suffix -no (data 2) is better in order to avoid the direct 
imposition of a request. Therefore, the use of the suffix -no in Javanese is more productive than the suffix -en. Syntactically, every verb which can be used by a suffix -en can be replaced by a suffix -no, but not vice versa as demonstrated by data (3) in

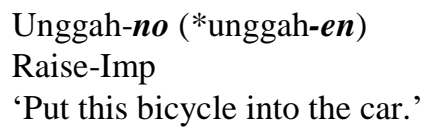

sepedah iki bicycle this

In terms of politeness, the requesting strategy of imperative mood as demonstrated by data (1), (2), and (3) is considered too direct in asking someone to do something because they deliver the speaker will explicitly. Consequently, this type of requesting strategy is only possible to address for the certain social contexts, such as the speaker is more powerful than the addressee $(\mathrm{P}: \mathrm{S}>\mathrm{H})$, e.g., an employer to his employee, the speaker is much older than his speech partner $(\mathrm{A}: \mathrm{S}>\mathrm{H})$, e.g. an older brother to his younger brother, or their social distance can be close, e.g. a parent to his son/daughter, or between an older brother to his younger brother.

\section{Direct strategy}

Linguistically, the direct strategy is marked by deleting the imperative suffixes (to be declarative moods), as demonstrated by an utterance (4). In the

$$
\begin{array}{lll}
\text { Aku } & \text { ny-(s)ilih } & \text { dhuwit-e! }(\mathrm{Ng}) \\
\text { you } & \text { Act.P-borrow } & \text { Motoro-this } \\
& \text { 'I wanto to borrow your money.' }
\end{array}
$$

$$
\begin{aligned}
& \text { Tulung umbah-no sepedah montor-ku } \\
& \text { Help wash-Imp cycle motor-my } \\
& \text { 'Please wash my motorcycle!' }
\end{aligned}
$$

Pragmatically, data (4) and (5) are considered more appropriate than those of data (1) to (3) because the sentences deliver the speaker's will more indirectly. As for the social contexts of the tenors, this type of requesting strategy is not so far different from those of the most direct strategy. The only possible difference is the age of the tenors, in which the speaker's age is older or equal to the speech partner $(A: S \geq H)$.

'Can you help (me) to pick up my younger brother/sister?'

$\begin{array}{llllll}\text { Opo } & \text { sampeyan }(\mathrm{KM}) & \text { iso } & \text { m-bantu } & \text { mapak } & \text { adik-ku? }(\mathrm{Ng}) \\ \text { QW } & \text { you } & \text { can } & \text { Act.P-help } & \text { pick up } & \text { younger-my }\end{array}$

\begin{tabular}{ccccl} 
Opo & aku & oleh & ny-(s)ilih & dhuwit-e? $(\mathrm{Ng})$ \\
QW & I & may & Act.P-borrow & money-the \\
\multicolumn{4}{r}{ 'Can I borrow some of your money?' } &
\end{tabular}

$\begin{array}{ll}\text { Kepriye saumpama } & \text { sampeyan(KM) } \\ \text { QW if } & \text { You }\end{array}$

'What do you think if you wash this car?' which an employer (the requester) asks his employee (the requestee) to do a service for him (the requester). In the utterance, the suffix -en does not work to replace the suffix $-n o$ (as indicated by the asterisk (*)).

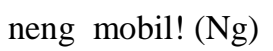

active declarative mood, the sentence is marked by the active prefix (Act.P) /N-/. This prefix always phonologically assimilates to the initial sound of the main verb into $n g$ - or $n y$-, or any other forms. Following is the request made by close friends.

Really, it is still possible to use an imperative mood in the direct strategy, but the strategy is commonly preceded by an expression of tulung 'asking a help, or please' as demonstrated by the following data, in which an older sister asks his younger brother to wash his motorcycle.

Linguisitically, the more appropriate way of utterance (5) can be examined from the disappearance of the imperative suffixes (such as en, or -no) which change the imperative mood into the declarative one, data (4), or by appearing the expression of the word tulung 'asking a help' or 'please' data (5).

\section{Less direct strategy}

In this strategy, the second person kowe 'you' which is from $\mathrm{Ng}$ level is replaced by the more respected lexicon taken from the KM level, sampeyan to show the more respective feeling. Next, the implicitness of the speaker's request to his speech partner can be realised by the next linguistic devices: an interrogative mood (data 6, and 7), or the combination of both an interrogative mood and a supposition/condition (data 8 and 9). ng-umbah montor iki $(\mathrm{Ng})$ ?
Act.P-clean 


\begin{tabular}{|c|c|c|c|c|c|c|}
\hline a. & $\begin{array}{l}\text { Yen } \\
\text { if }\end{array}$ & $\begin{array}{c}\text { (sampeyan) } \\
\text { (you) }\end{array}$ & $\begin{array}{l}\text { ono, } \\
\text { have }\end{array}$ & $\begin{array}{c}\text { aku } \\
\text { I }\end{array}$ & $\begin{array}{l}\text { ny-(s)ilih } \\
\text { Act.P-borrow }\end{array}$ & $\begin{array}{l}\text { dhuwit-e }(\mathrm{Ng}) ? \\
\text { money-the }\end{array}$ \\
\hline
\end{tabular}

'If you have some money, may I borrow some?'

$\begin{array}{clcclll}\text { b. Kepriye } & \text { yen } & \text { aku } & \text { ny-(s)ilih } & \text { dhuwit-e, } & \text { opo (sampeyan) } & \text { duwe? (Ng) } \\ \text { how } & \text { if } & \text { I Act.P-borrow } & \text { money-the } & \text { QW (you) } & \text { have }\end{array}$

'Lit. What is your opinion if I want to borrow some money, do you have it?'

Linguistically, the more polite strategy of delivering requests in Javanese can be examined from the choice of the lexicon, and the change of the mood type (from declarative mood into interrogative one). In term of the degree of politeness, the second person pronoun sampeyan 'you' is more polite than the pronoun kowe. Syntactically, an interrogative mood can give a chance or a choice to the speech partner to respond (to reject) to the request. Further open options for responding the requests can be done by applying not only an interrogative mood but the use of a conditional form as well. Following Lakoff's rules of politeness, data (6) to (9) are considered to be more appropriate than data (4) and
(5) because the later styles which use interrogative moods (6) and (7), or an imperative mood and a supposition/condition, data (8) and (9), can be said that the requesting acts do not impose, because there is a more space for the addressees to refuse or to comply the requests.

A further linguistic device which can be used to improve the degree of politeness of delivering the request in Javanese is a passive voice form. There are two forms of passive voice. They are a passive voice with an overt agent construction and the one with an agentless construction, as demonstrated by the following data.

$\begin{array}{cllll}\text { Kepriye } & \text { saumpama } & \text { Mobil } & \text { iki } & \text { Sampeyan-umbah?(Ng) } \\ \text { how } & \text { if } & \text { Car } & \text { this } & \text { you.Passive-cleaned }\end{array}$

'Lit. What is your opinion If this car was washed by you?'

Kepriye saumpama Mobil iki di-umbah?(Ng)
how if
'Lit. What is your opinion If this car was washed by you?'

The utterance (10) shows a passive sentence with an overt agent. The subject of the sentence is mobil iki 'this car' and the verb is umbah 'clean'. The agent of the verb umbah is the second person pronoun sampeyan 'you'. In this requesting act, it is clear that the speaker asks his speech partner to perform an action, umbah 'clean'. In contrast, the di-verb form (passive) construction, (11) does not display an overt agent. Consequently, the action of the verb umbah can be interpreted 'to be done by the addressee or someone else'. In this case, the context of the utterance will usually help us to determine who will do the action. As for the social contexts of the tenors, this type of requesting strategy is commonly used in the following social contexts. It is mostly addressed to someone whose social status is equal $(\mathrm{P}: \mathrm{S}=\mathrm{H})$, their social distance is close or middle, and their ages are older or equal $(\mathrm{A}: \mathrm{S} \geq \mathrm{H})$.

\section{Indirect Strategy}

This indirect strategy is considered to be the most appropriate one in Javanese, and linguistically, this strategy is mostly marked by the use of KI speech level in which most of the lexicons are expressed in KI forms appropriately. Let us pay attention the following requesting act which was made by a cousin to his uncle who was studying in Melbourne, Australia. The social context is the speaker is much younger than the addressee $(\mathrm{A}: \mathrm{S}<\mathrm{H})$, the speaker is less powerful $(\mathrm{P}: \mathrm{S}<\mathrm{H})$, and their social distance is middle ( $\mathrm{SD}$ : middle).

$$
\begin{aligned}
& \text { (12) Menawi (KI) } \begin{array}{c}
\text { wonten (KI), kula (KI) } \\
\text { available Panj }
\end{array} \\
& \text { 'If it is available, can you bring me a warm jacket?' } \\
& \text { In term of speech level, the request of (12) is } \\
& \text { marked by the use of KI lexicons (e.g., menawi from } \\
& \text { yen 'if', wonten from ono 'available', panjenengan } \\
& \text { from sampeyan (KM) or kowe (Ng) 'you'. However, } \\
& \text { this requesting act is still considered less } \\
& \text { appropriate, and so is too direct pragmatically } \\
& \text { because the request is delivered to a person whose }
\end{aligned}
$$

status is higher than the speaker's. Although the requester and the requestee may socially be close (a cousin and his uncle), such a request can imply the cost of imposition which may cause the requestee losing his face (FTA). Consequently, it is very often that the speaker creates a situation (a supposition) which enables him to make a request more politely. 
Thus, a supposition such as mboten ngrepoti 'not making you any trouble' and sedoyo urusan sampun cekap 'everything has been fixed' is often introduced before he really delivers his request, as demonstrated by (13).

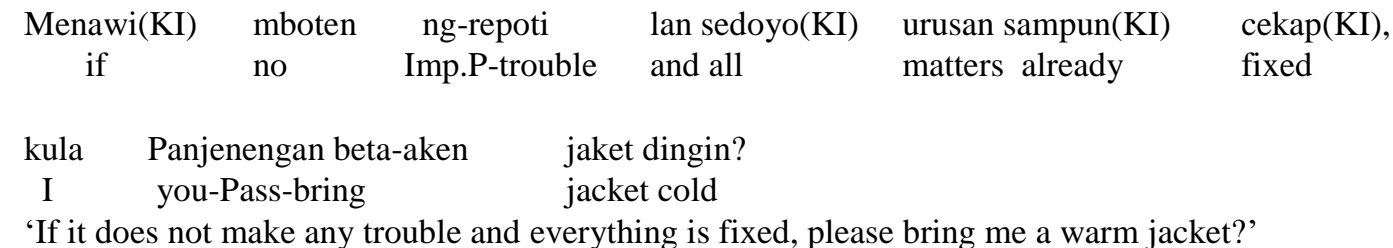

The degree of politeness of (13) is much better than of (15) which is indicated by the creating of a supposition: menawai mboten ngrepoti or a condition: lan sedoyo urusan sampun cekap prior to the request. Supposition, as well as condition, have really made the addressee feel good because he has got more chances to get free from the request compared to data (12). In data (12), the addressee has only got one chance menawi wonten 'if it is available' to reject the request and the reason of rejecting is less reasonable since the warm jacket is really easy to find in a cold city like Melbourne.

In addition, the degree of politeness of (13) is still possible to be upgraded by two following linguistic devices (1) by deleting the agent panjenengan 'you' as required by the agentless passive construction, and (2) by changing the declarative mood of the main clause into an interrogative one, as demonstrated by (14).

$$
\begin{aligned}
& \text { (14) Menawi(KI) Mboten(KI) ng-repoti lan sedoyo(KI) urusan sampun(KI) cekap(KI), } \\
& \text { if No Imp.P-trouble and all matters already Fixed } \\
& \begin{array}{cclll}
\text { menopo(KI) saget(KI) } & \text { kula(KI) } & \text { dipun-beta-aken } & \text { jaket } & \text { dingin? } \\
\text { Whether can } & \text { I } & \text { Pass.P.-bring-Suf } & \text { jacket } & \text { Cold }
\end{array}
\end{aligned}
$$

Another possible context to use such an indirect strategy is the size of imposition. If a speaker makes a request for a big thing, such a new motorcycle, it is very possible to choose an indirect strategy as shown by the following conversation between a son and his father. The speech level is KI (15a).

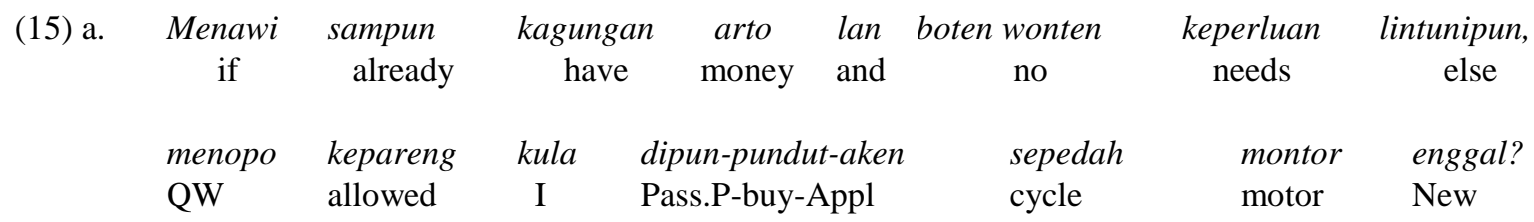

'If you have a lot of money, and have no other needs, can you buy me a new motorcycle?'

$\begin{array}{lllll}\text { b. Ya, Yen } & \text { Bapak wis } & \text { oleh } & \text { rezeki }(\mathrm{Ng}) \\ \text { yes If } & \text { Father already get } & \text { money } \\ \text { 'It's OK, when I have got much money.' } & \end{array}$

Both data (14) and (15a) are considered very polite (indirect strategy) which are marked by the following linguistic units: (1) interrogative mood, (2) agentless passive construction, (3) supposition and condition, and (4) KM level. The deletion of the agent in the request act can hide the requester because it does not appear clearly (or directly) in the utterance. In addition, this agentless passive construction enables the speaker to give an order without addressing it directly to the addressee. Accordingly, the deletion of the requester as well as the use of the question word-order menopo saget (14) and menopo kepareng (15a) meaning 'could you' rather than a direct order make the requesting acts most polite among the request variants above. Like Mexican requests (Felix-Brasdefer, 2005), it is also found in Javanese that indirectness (linguistic markers) is closely related to politeness.

\section{CONCLUSION}

This research set out to investigate the requesting utterances of Javanese spoken in Jember, East Java, Indonesia in various situations and purposes. According to the politeness patterns, there can be found four types of politeness strategies. They are 
the most direct, direct, less direct, and indirect strategies. Each pattern of the politeness strategies is marked by the linguistic units such as sentence moods (imperatives, declaratives, and interrogatives), speech levels ( $\mathrm{Ng}, \mathrm{KM}$, and $\mathrm{KI}$ ), voices (active, and passive constructions), and supposition or condition. Next, the choice of the appropriate requesting strategies is determined by the social context of the tenors or interlocutors of the requesting utterances, including the social distance, age, social status or power, age, and the size of imposition. Finally, to be polite in delivering requests in Javanese, one must be able to choose the appropriate speech styles depending on the social relationship between the interlocutors, to make requests further from the speaker's view (e.g. using an interrogative form, creating a supposition or condition) which will make the addressee feel good, and to delete the recipient of the order from the request forms (e.g. by using the agentless passive construction). The combination of using interrogative forms, supposition/condition, as well as agentless passive forms makes the indirect or offrecord requests become the most polite in delivering requests in Javanese. The interface between the politeness strategies and the linguistic units in Javanese can be concluded that the more indirect and complicated the linguistic units used, the more polite the requesting strategy will be.

These study's results may have come to this conclusion because it is only limited to Javanese spoken in Jember and applied only to a limited number of participants. It also might be useful for the future researchers to do the same research on large sample size both across different groups of Javanese which are spread in many different areas as well as using different research methodologies in order to be able to make generalization more precisely.

\section{REFERENCES}

Abuarrah, S., Lochtman, K., and Lutjerhams, M. (2013). Cross-cultural pragmatics requests use of strategy and level of directness in Palestinian Arabic and British English. AnNajah Univ. J. Res. (Humanity), 27 (5), 11091143.

Alsulami, S. Q. (2015). The effectiveness of social distance on requests. Arab World English Journal, 6 (3), 382-395.

Anderson, J.A. (2009). Polite requests in non-native varieties of English: The case of

Ghanaian English. Linguistica Atlantica, $30,59-86$

Aziz, A.A. (2017). Agreement strategies among Malaysian Chinese speakers of English. $3 L$ :

The Southeast Asian Journal of English Language Studies, 23 (1), 168 -189.
Aubed, M. M. (2012). Polite requests in English and Arabic: A comparative study. Theory and Practice in Language Studies, 2 (5), 916-922.

Aubed, M. M. (2012). Polite requests in English and Arabic: A comparative study. Theory and Practice in Language Studies, 2 (5), 916-922.

Banikalef, A. A. A., Maros, M., Aladdin, A., \& Al-natour, M. (2015). Apology strategies in Jordanian Arabic. GEMA Online Journal of Language Studies, 15 (2), 83 - 99.

Brown, P. \& S. C. Levinson. (1987). Politeness: Some universal in language usage. Cambridge: Cambridge University Press.

Blum-Kulka, S. (1987). Indirectness and politeness in requests: Same or different? Journal of Pragmatics, 11, 131-146.

Blum-Kulka, S., House, J., \& Kasper, G. (1989). Cross-cultural pragmatics: Requests and apologies. Norwood, NJ: Ablex.

Chen, R. (1993). Responding to compliments: A contrastive study of politeness between American English and Chinese speakers. Journal of Pragmatics, 20, 49-70.

Chen, R. (1996). Food-plying and Chinese politeness. Journal of Asian Pacific Communication, 7 (3/4), 43-155.

Chiravate, B. (2012). Perception of politeness in English requests by Thai EFL learners. 3L: The Southeast Asian Journal of English Language Studies 17 (2), 59-71.

Errington, J. (1988). Structure and style in Javanese Pennsylvania: The University of Pennsylvania Press.

Felix-Brasdefer, J. C. (2005). Indirectness and politeness in Mexican requests. in Selected Proceedings of the $7^{\text {th }}$ Hispanic Linguistics Symposium, (Ed.) D. Eddington, pp. 66-78. Somerville, MA: Cascadilla Proceeding Project.

Gonda, J. (1949). The Javanese vocabulary of courtesy. Lingua, 1, 333-376.

Herrick, E. M. (1984). Levels of respect in Javanese. In Sociolinguistic Variation (pp. 80-98). Albama: The University of Albama Press.

Kadarisman, A.E. (1999). Wedding narratives as verbal art performance: Exploration in Javanese poetics, (unpublished Ph.D. thesis). Hawai: University of Hawai.

Lakoff, R. (1973). The logic of politeness, or minding your p's and q's'. Papers from the Ninth Regional Meeting of the Chicago Linguistics Society, 9, 292-305.

Lee, S. K. (2003). Exploring the relationship between language, culture, and identity. GEMA Online Journal of Language Studies, 3 (4), 113.

Leech, G. (1983). Principles of pragmatics. New York. Longman. 
Mao, L. (1992). Invitational discourse and Chinese identity. Journal of Asian Pacific Communication, 3, 79-96.

Maros, M., \& Rosli, L. (2017). Politeness strategies in twitter updates of female English language studies Malaysian undergraduates English. 3L: The Southeast Asian Journal of English Language Studies, 23 (1), 132- 49.

Mrazek, J. (1998). Phenomenology of puppet theater: Contemplations on the performance technique of contemporary Javanese wayang kulit. Ph.D. Thesis (Unpublished). Cornel University.

Partana, P. (2006). Tindak tutur tak langsung bahasa Jawa: Studi metapesan pada masyarakat tutur Jawa di Surakarta. Linguistika Jawa, 2 (1), 113.

Poedjosoedarmo, S. (1979). Tingkat tutur bahasa Jawa. Jakarta: Pusat Pembinaan dan Pengembangan Bahasa. DEPDIKBUD.

Quinn, G. (2011). Teaching Javanese respect usage to Foreign Learners. Electronic Journal of Foreign Language Teaching, 8, 362-370.

Salmani Nodoushan, M. A. (2007). Politeness markers in Persian requestives. The Linguistics Journal, 2 (1), 43-68.

Salvesen, K. E. (2015). Politeness strategies in requests by Norwegian learners of English in comparison with native speakers of English. Hawaii Pacific University TESOL Working Paper Series, 13, 53-69.

Searle, J. (1975). Indirect speech acts. In Peter Cole \& Jerry L. Morgan (Eds.), Syntax and Semantics (pp. 59-82). New York: NY: Academic Press.

Sulistyowati. (2008). Alternasi sapaan bahasa Jawa di keraton Yogyakarta. Humaniora: Jurnal of
Culture, Literature, and Linguistics, 20 (2), 168-178.

Sukarno. (2008). The Study on interpersonal meanings in Javanese wedding pranatacara genre. Humaniora, Jurnal Budaya, Sastra, dan Bahasa, 20 (2), 200 - 209.

Sukarno. (2010). The reflection of the Javanese cultural concepts in the politeness of Javanese. $K @ \operatorname{ta}, 12(1), 59-71$.

Sukarno. (2015). Politeness strategies in responding to compliments in Javanese. Indonesian Journal of Applied Linguistics, 4(2), 226-236.

Syahri, I. (2013). Resemblance of indirectness in politeness of EFL learners' request

Realizations. Indonesian Journal of Applied Linguistics, 3(1):148 - 165.

Uhlenbeck, E.M. (1970). Two mechanisms of Javanese syntax: The construction with sing (kang, ingkang) and with olehe (enggone, anggonipun). in A. Halim, L. Carrington, \& S.A. Wurm (Eds.), Pacific Linguistics Series C (pp. 77-89). Canberra: Research School of Pacific Studies, ANU.

Watts, R.J., Ide, S., \& Ehlich, K. (1992). Politeness in language studies in its history: Theory and practice. Berlin: Mouton de Gruyter.

Wierzbicka, A. (1992). Semantics, culture, and cognition: Universal human concepts in cultural-specific configurations. Oxford: Oxford University Press.

Wolff, J.U., \& Poedjosoedarmo, S. (1982). Communicative code in Central Java. Linguistic Series $8^{\text {th }}$. New York: Cornel University.

Zaid, A. (1999). Strategies for communication between superior and subordinates. Ph.D. Thesis (unpublished). Malang: Malang State University. 